\title{
Upaya Meningkatkan Ketrampilan Writing Skill pada Teks Interaksi Interpersonal dengan Menerapkan Teknik Pembelajaran Total Physical Response (Pada Siswa Kelas VII A SMP Negeri 8 Muaro Jambi)
}

\author{
Astuti \\ Guru SMP Negeri 8 Muaro Jambi \\ Correspondence email: astutib0@gmail.com
}

\begin{abstract}
Abstrak. Tujuan dari penelitian ini untuk mengetahui dan meningkatkan ketrampilan writing skill pada teks interaksi interpersonal. Penelitian ini menggunakan dua metode pembelajaran yaitu metode konvesional pada kondisi prasiklus awal dan teknik pembelajaran Total Physical Response. Proses pembelajaran dibagi menjadi tiga tahap yakni tahap pertama adalah prasiklus dengan menggunakan metode konvensional, tahap kedua siklus 1 dengan metode Total Physical Response dan tahap ke tiga siklus 2 juga menggunakan metode Total Physical Response. Hasil penelitian menunjukkan bahwa pada prasiklus peneliti masih menggunakan metode konvensional dalam pembelajaran, siswa yang tuntas belajar pada prasiklus hanya 11 siswa atau $42 \%$ siswa yang tuntas belajar. Kemudian pada siklus 1 peneliti mengadakan perbaikan pembelajaran dengan menerapkan Tekhnik Pembelajaran Total Physical Response. Hasilnya adalah pada siklus 1 ini jumlah siswa yang tuntas belajar meningkat menjadi 20 siswa atau 77\% siswa mampu tuntas belajar. Pada siklus 2 terdapat peningkatan jumlah siswa tuntas belajar menjadi 24 siswa atau 92\% siswa mampu tuntas belajar. Sehingga dapat di simpulkan dalam jangka waktu kurang lebih 2 minggu, dengan konsep 4X pertemuan. Penerapan Tekhnik Pembelajaran Total Physical Response berdampak positif bagi proses peningkatan ketrampilan writing skill siswa pada Teks Interaksi Interpersonal di Kelas VII A SMP Negeri 8 Muaro Jambi.
\end{abstract}

Kata Kunci: Writing Skill, Teks Interaksi Interpersonal, Tekhnik Pembelajaran Total Physical Response.

\begin{abstract}
The purpose of this study is to find out and improve writing skills in interpersonal interaction texts. his study uses two learning methods, namely the conventional method in the initial pre-cycle conditions and the Total Physical Response learning technique. The learning process is divided into three stages are the first stage is pre-cycle using conventional methods, the second stage of cycle 1 with the Total Physical Response method and the third stage of cycle 2 also uses the Total Physical Response method. The results showed that in the pre-cycle researchers were still using conventional methods in learning, only 11 students completed the study in the pre-cycle or $42 \%$ of students had finished learning. Then in cycle 1 the researcher conducted an improvement in learning by applying the Total Physical Response Learning Technique. The result is that in cycle 1 the number of students who have completed learning has increased to 20 students or $77 \%$ of students who have completed learning. In cycle 2 there was an increase in the number of students completing learning to 24 students or $92 \%$ of students being able to complete learning. So that it can be concluded in a period of approximately 2 weeks, with the concept of $4 X$ meetings. The application of Total Physical Response Learning Techniques has a positive impact on the process of improving students' writing skills in Interpersonal Interaction Texts in Class VII A, SMP Negeri 8 Muaro Jambi.
\end{abstract}

Keywords: Writing Skill, Interpersonal Interaction Text, Total Physical Response Learning Techniques.

\section{PENDAHULUAN}

Kegiatan belajar mengajar merupakan proses dimana seorang guru memberikan sebuah pendidikan kepada siswa dalamsuatu instansi yang di sebut sekolah. Guru merupakan pusat pembelajaran yang memegang peranan sangat penting dalam memberikan pemahaman. Perubahan paradigma dalam pendidikan menuntut pembelajaran berpusat pada siswa. Guru bukanlagi sebagai pusat pembelajaran, melainkan bertindak sebagai fasilitator dan motivator. Pemilihan tekhnik pembelajaran juga harus tepat. Sebagai seorang guru harus bisa menerapkan strategi belajar yang baik. Seperti halnya guru bahasa inggris, yang di dalamnya berupaya mengajarkan dan memberikan ketrampilan kepada siswa untuk menguasai bahasa asing. Bahasa merupakan kunci penentu menuju keberhasilan dan memiliki peran sentral, khususnya dalam perkembangan intelektual, sosial, dan emosional seseorang dan dalam mempelajari semua bidang studi. Bahasa diharapkan bisa membantu seseorang dalam hal ini yang saya bicarakan adalah peserta didik untuk mengenal dirinya, budayanya dan budaya orang lain, mengemukakan gagasan dan perasaan, berpartisipasi dalam masyarakat yang menggunakan bahasa tersebut, menemukan serta menggunakan kemampuan-kemampuan analitis dan imaginative dalam dirinya.

Saat ini bahasa Inggris merupakan mata pel ajaran yang dikaji oleh setiap jenjang kelas di sekolah. Termasuk juga di kelas VII pada tingkat Sekolah Menengah Pertama. Salah satu materi yang di ajarkan adalah Teks interaksi interpersonal. Pada materi ini salah satu aspek yang diharapkan adalah siswa dapat meningkatkan ketrampilannya dalam menulis Teks interaksi interpersonal. 
Salah satu tekhnik pembelajaran yang tepat dalam pembelajaran bahasa inggris adalah Tekhnik Pembelajaran Total Physical Response. TPR (Total Physical Response) merupakan suatu metode pembelajaran bahasa yang disusun pada koordinasi perintah (command), ucapan (speech) dan gerak (action); dan berusaha untuk mengajarkan bahasa melalui aktivitas fisik (motor).Metode TPR ini sangat mudah dan ringan dalam segi penggunaan bahasa dan juga mengandung unsur gerakan permainan sehingga dapat menghilangkan stress pada peserta didik karena masalahmasalah yang dihadapi dalam pelajarannya terutama pada saat mempelajari bahasa asing, dan juga dapat menciptakan suasana hati yang positif pada peserta didik yang dapat memfasilitasi pembelajaran sehingga dapat meningkatkan motivasi dan prestasi siswa dalam pelajaran tersebut. Makna atau arti dari bahasa sasaran dipelajari selama melakukan aksi.

Berdasarkan uraian datas, maka perlu dilakukan suatu tindakan berupa penerapan Tekhnik Pembelajaran Total Physical Response untuk meningkatkan writing skill pada Teks interaksi interpersonal. Oleh karena itu peneliti tertarik untuk melakukan penelitian yang berjudul "Upaya meningkatkan ketrampilan writing skill pada teks interaksi interpersonal dengan menerapkan tekhnik pembelajaran total physical response pada siswa kelas VII A SMP Negeri 8 Muaro jambi tahun pelajaran 2016/2017".

Tujuan dari penelitian ini adalah untuk mengetahui upaya meningkatkan ketrampilan writing skill pada Teks interaksi interpersonal dengan menerapkan tekhnik pembelajaran total physical response pada siswa kelas VII A SMP Negeri 8 Muaro Jambi Tahun Pelajaran 2016/2017.

\section{Landasan Teori}

\section{Pengertian Writing Skill}

Writing adalah suatu kegiatan untuk menciptakan suatu catatan atau informasi pada suatu media dengan menggunakan aksara. Henry Guntur Tarigan (1986: 15) menyatakan bahwa menulis dapat diartikan sebagai kegiatan menuangkan ide/gagasan dengan menggunakan bahasa tulis sebagai media penyampai. Menurut Djago Tarigan dalam Elina Syarif, Zulkarnaini, Sumarno (2009: 5) menulis berarti mengekpresikan secara tertulis gagasan, ide, pendapat, atau pikiran dan perasaan. Lado dalam Elina Syarif, Zulkarnaini, Sumarno (2009: 5) juga mengungkapkan pendapatnya mengenai menulis yaitu: meletakkan simbol grafis yang mewakili bahasa yang dimengerti orang lain.

Menulis dapat dianggap sebagai suatu proses maupun suatu hasil. Menulis merupakan kegiatan yang dilakukan oleh seseorang untuk menghasilkan sebuah tulisan. Menurut Heaton dalam St. Y. Slamet (2008: 141) menulis merupakan keterampilan yang sukar dan kompleks.

Menurut Gebhardt dan Dawn Rodrigues (1989: 1) writing is one of the most important things you do in college. Menulis merupakan salah satu hal paling penting yang kamu lakukan di sekolah. Kemampuan menulis yang baik memegang peranan yang penting dalam kesuksesan, baik itu menulis laporan, proposal atau tugas di sekolah.

Menurut Eric Gould, Robert DiYanni, dan William Smith (1989: 18) menyebutkan writing is a creative act, the act of writing is creative because its requires to interpret or make sense of something: a experience, a text, an event. Menulis adalah perilaku kreatif, perilaku menulis kreatif karena membutuhkan pemahaman atau merasakan sesuatu: sebuah pengalaman, tulisan, peristiwa.

\section{Pengertian Teknhik Pembelajaran}

Menurut Kamus Dewan (edisi ketiga), tehnik adalah pengetahuan tentang cara mencipta sesuatu hasil seni seperti muzik, karang-mengarang dan sebagainya. Menurut Edward M. Anthony mendefinisikan tehnik adalah suatu cara strategi atau taktik yang digunakan oleh guru untuk mencapai hasil yang maksimum pada waktu mengajar pada bagian pelajaran tertentu.

Sedangkan menurut Kamaruddin Hj. Husin \& Siti Hajar Hj. Abdul Aziz dalam bukunya Pengajian Melayu III : Teknik bisa didefinisikan sebagai pengendalian suatu organisasi yang benar-benar berlaku di dalam pengajaran yang digunakan untuk mencapai suatu objektif.Teknik merupakan suatu alat yang digunakan oleh guru untuk menyampaikan bahan-bahan pengajaran yang telah dipilih untuk peserta didik. Tehnik yang dipilih haruslah sesuai dengan pelajaran yang digunakan dan seirama dengan pendekatan yang digunakan.

Menurut Kamus Besar bahasa Indonesia (2005: 1158) teknik adalah metode atau sistem mengerjakan sesuatu, cara membuat atau seni melakukan sesuatu. Gerlach dan Ely (Hamzah B Uno, 2009: 2) mengartikan teknik sebagai jalan, alat, atau media yang digunakan oleh guru untuk mengarahkan kegiatan peserta didik kearah tujuan yang ingin dicapai. Teknik secara harfiah juga diartikan sebagai cara yang dilakukan seseorang dalam mengaplikasikan dan mempraktikkan suatu metode.

\section{Aspek Writing Skill}

Terdapat 4 aspek untuk Writing. Secara singkat, kriterianya adalah sebagai berikut:

a. Task fulfiment atau disebut juga Task Achievement dan Task Response. (menjawab pertanyaan dengan penuh) 
Astuti, Upaya Meningkatkan Ketrampilan Writing Skill pada Teks Interaksi Interpersonal dengan Menerapkan Teknik Pembelajaran Total Physical Response (Pada Siswa Kelas VII A SMP Negeri 8 Muaro Jambi)

b. Coherence dan Cohesion. (Kata, Kalimat, Paragraf menyatu secara halus. semuanya berurutan secara logis

c. Lexical Resource. (Kota kasa)

d. Grammatical Range dan Accuracy. (Grammar)

\section{Pengertian Total Physical Response (TPR)}

Menurut Richards J dalam bukunya Approaches and Methods in Language Teaching, TPR didefinisikan suatu metode pembelajaran bahasa yang disusun pada koordinasi perintah (command), ucapan (speech) dan gerak (action); dan berusaha untuk mengajarkan bahasa melalui aktivitas fisik (motor).

Sedangkan menurut Larsen dan Diane dalam Technique and Principles in Language Teaching, TPR atau disebut juga "the comprehension approach" atau pendekatan pemahaman yaitu suatu metode pendekatan bahasa asing dengan instruksi atau perintah. Metode ini dikembangkan oleh seorang professor psikologi di Universitas San Jose California yang bernama Prof. Dr. James J. Asher yang telah sukses dalam pengembangan metode ini pada pembelajaran bahasa asing pada anak-anak. Ia berpendapat bahwa pengucapan langsung pada anak atau siswa mengandung suatu perintah, dan selanjutnya anak atau siswa akan merespon kepada fisiknya sebelum mereka memulai untuk menghasilkan respon verbal atau ucapan.

Metode TPR ini sangat mudah dan ringan dalam segi penggunaan bahasa dan juga mengandung unsur gerakan permainan sehingga dapat menghilangkan stress pada peserta didik karena masalah-masalah yang dihadapi dalam pelajarannya terutama pada saat mempelajari bahasa asing, dan juga dapat menciptakan suasana hati yang positif pada peserta didik yang dapat memfasilitasi pembelajaran sehingga dapat meningkatkan motivasi dan prestasi siswa dalam pelajaran tersebut. Makna atau arti dari bahasa sasaran dipelajari selama melakukan aksi.

\section{Tujuan Tekhnik Pembelajaran Total Physical Response}

Metode TPR bagi guru, bertujuan agar tercipta suasana yang nyaman sehingga siswa dapat menikmati pembelajaran dan dapat belajar untuk berkomunikasi menggunakan bahasa asing dengan baik. Hals ini dikarenakan pada dasarnya metode TPR ini dikembangkan untuk mengurangi tekanan bagi siswa di dalam kelas, dan membuat suasana kelas menyenangkan. (Larson-Freeman, 1986: 116).

\section{METODE}

Pokok bahasan dalam Penelitian Tindakan Kelas (PTK) ini adalah "Upaya Meningkatkan Ketrampilan Writing Skill Pada Teks Interaksi Interpersonal Dengan Menerapkan Tekhnik Pembelajaran Total Physical Response Pada Siswa Kelas VII A SMP Negeri 8 Muaro Jambi Tahun Pelajaran 2016/2017 dengan melibatkan 26 siswa peserta didik.

Rancangan penelitian ini menggunakan Penelitian Tindakan Kelas (Classromm Activity Research) dengan menggunakan empat alur (langkah): (1) perencanaan tindakan; (2) pelaksanaan tindakan; (3) Pengamatan; (4) refleksi.

Sebelum melaksanakan tindakan, terlebih dahulu peneliti merencanakan secara seksama jenis tindakan yang akan dilakukan. Kedua, setelah rencana disusun secara matang, barulah tindakan itu dilakukan. Ketiga, bersamaan dengan dilaksanakan tindakan, peneliti mengamati proses pelaksanaan tindakan itu sendiri dan akibat yang ditimbulkannya. Keempat, berdasarkan hasil pengamatan tersebut, peneliti kemudian melakukan refleksi atas tindakan yang telah dilakukan. Jika hasil refleksi menunjukkan perlunya dilakukan perbaikan atas tindakan yang telah dilakukan, maka rencana tindakan perlu disempurnakan lagi agar tindakan yang dilaksanakan berikutnya tidak sekedar mengulang apa yang telah diperbuat sebelumnya. Demikian seterusnya sampai masalah yang diteliti dapat mengalami kemajuan.

Adapun rancangan penelitian tindakan kelas ini dilakukan dalam II siklus. Dengan catatan: Apabila siklus I berhasil sesuai kriteria yang diinginkan, maka tetap dilakukan siklus II untuk pemantapan, tetapi kalau siklus I tidak berhasil, maka dilakukan siklus II dengan cara menyederhanakan materi dan menambah media pembelajaran. Apabila pada siklus II belum terjadi peningkatan, maka siklus III harus dipersiapkan untuk mengatasi kesulitan yang dialami siswa.

\section{Prosedur Penelitian Pra Siklus \\ Perencanaan}

Pada tahap perencanaan, peneliti merencanakan kegiatan yang akan dilakukan pada Penelitian Tindakan Kelas (PTK), adapun kegiatan yang akan dilakukan dalam perencanaan adalah sebagai berikut :

- Membuat rencana pelaksanaan pembelajaran

- Membuat lembar pengamatan

- Membuat alat evaluasi 
Astuti, Upaya Meningkatkan Ketrampilan Writing Skill pada Teks Interaksi Interpersonal dengan Menerapkan Teknik Pembelajaran Total Physical Response (Pada Siswa Kelas VII A SMP Negeri 8 Muaro Jambi)

\section{Pelaksanaan Tindakan}

Pelaksanaan Pra Siklus dilaksanakan selama 2 x 40 menit Pelaksanaan pra siklus berdasarkan RPP terlampir.

\section{Pengamatan}

Pada pengamatan, penelitian sebagai guru pengajar melakukan tindakan yaitu pembelajaran Teks interaksi interpersonal dengan aspek writing skill. Pengamatan di lakukan oleh guru bahasa inggris yang disini berperan sebagai peneliti.Dengan menggunakan lembar pengamatan untuk mengamati hasil peningkatan ketrampilan writing skill siswa pada Teks interaksi interpersonal melalui metode konvensioanal pada siswa Kelas VII A tahun pelajaran 2016/2017 (format lembar pengamatan terlampir)

\section{Refleksi}

Pada tahap refleksi, peneliti mengevaluasi hasil tindakan yang telah dilaksanakan pada tahap pra siklus, kemudian bila perlu merevisi tindakan sebelumnya untuk dilaksanakan pada tahap berikutnya.

\section{Prosedur Penelitian Pada Siklus I \\ Perencanaan}

Pada tahap ini peneliti merumuskan dan mempersiapkan: rencana jadwal pelaksanaan tindakan, rencana pelaksanaan pembelajaran, materi/bahan pelajaran sesuai dengan pokok bahasan, lembar tugas siswa, lembar penilaian hasil belajar, instrumen lembar observasi, dan mempersiapkan kelengkapan lain yang diperlukan dalam rangka analisis data.

\section{Pelaksanaan Tindakan}

Pelaksanaan Siklus I dilaksanakan selama 4 x 40 menit (2 x pertemuan). Pelaksanaan siklus I berdasarkan RPP terlampir.

Pelaksanaan tindakan pada dasarnya disesuaikan dengan setting tindakan yang telah ditetapkan dalam rencana pelaksanaan pembelajaran (RPP). Pelaksanaan tindakan dalam penelitian ini dilakukan sesuai dengan langkah-langkah pembelajaran pada pola dan tahapan pembelajaran dengan tehnik pengamatan objek secara langsung sesuai dengan RPP terlampir

\section{Pengamatan}

Saat proses pembelajaran berlangsung dilakukan pengamatan terhadap perilaku siswa. Pengamatan dilakukan untuk mengetahui sejauh mana Tekhnik Pembelajaran Total Physical Response dalam meningkatkan ketrampilan writing skill siswa pada Teks interaksi interpersonal. Pelaksanaan pengamatan mulai awal pembelajaran ketika guru melakukan apersepsi sampai akhir pembelajaran.( format pengamatan terlampir )

\section{Refleksi}

Refleksi merupakan kegiatan menganalisis semua data atau informasi yang dikumpulkan dari penelitian tindakan yang dilaksanakan, sehingga dapat diketahui berhasil atau tidaknya tindakan yang telah dilaksanakan dengan tujuan yang diharapkan.

\section{Prosedur Penelitian Siklus II}

Berdasarkan refleksi pada siklus I, diadakan kegiatan-kegiatan untuk memperbaiki rencana dan tindakan yang telah dilakukan. Langkah-langkah kegiatan pada siklus II pada dasarnya sama seperti langkah-langkah pada siklus I, tetapi ada beberapa perbedaan kegiatan pembelajaran pada siklus II.

\section{Perencanaan}

Sebagai tindak lanjut siklus I, dalam siklus II dilakukan perbaikan. Peneliti yang dalam hal ini adalah guru bahasa inggris mencari kekurangan dan kelebihan pada peningkatan ketrampilan writing skill siswa pada Teks interaksi interpersonal melalui Tekhnik Pembelajaran Total Physical Response pada siklus I. Kelebihan yang ada pada siklus I dipertahankan pada siklus II, sedangkan kekurangannya diperbaiki. Penulis juga menyiapkan pedoman wawancara, lembar observasi untuk mengetahui peningkatan ketrampilan writing skill siswa pada Teks interaksi interpersonal setelah di terapkan Tekhnik Pembelajaran Total Physical Response . 
Astuti, Upaya Meningkatkan Ketrampilan Writing Skill pada Teks Interaksi Interpersonal dengan Menerapkan Teknik Pembelajaran Total Physical Response (Pada Siswa Kelas VII A SMP Negeri 8 Muaro Jambi)

\section{Pelaksanaan Tindakan}

Pelaksanaan Siklus II dilaksanakan selama 2 x 40 menit ( 2 x pertemuan ) Proses tindakan pada siklus II dengan melaksanakan proses pembelajaran berdasarkan pada pengalaman hasil dari siklus I. Dalam tahap ini peneliti melaksanakan proses pembelajaran berdasarkan Tindakan pada siklus I.

\section{Pengamatan}

Adapun yang diamati pada siklus II sama seperti siklus I, meliputi: hasil tes dan nontes (pengamatan dan wawancara). Pedoman pengamatan pada siklus II memperhatikan instrumen serta kriteria seperti yang terdapat pada siklus I.

Refleksi

Refleksi merupakan kegiatan menganalisis semua data atau informasi yang dikumpulkan dari penelitian tindakan yang dilaksanakan, sehingga dapat diketahui berhasil atau tidaknya tindakan yang telah dilaksanakan pada siklus II dengan tujuan yang diharapkan.

Teknik analisis data yang digunakan secara deskreptif yaitu hanya mengumpulkan data yang diperoleh melalui pengamatan dan tes hasil belajar di susun, dijelaskan, dan akhirnya di analisis dalam dua tahapan yaitu:

\section{Reduksi Data}

Reduksi data merupakan suatu proses pemilihan, pemusatan dan perbaikan pada penyederhanaan data. Pada tahap reduksi data pengamatan terhadap proses pembelajaran Teks interaksi interpersonal pada aspek writing skill.

\section{Display Data (Penyajian Data)}

Data yang diperoleh melalui pengamatan dan tes hasil belajar berbentuk tabel dan kalimat sederhana setiap putaran.

\section{HASIL PENELITIAN DAN PEMBAHASAN}

Hasil belajar pada pra siklus Ketrampilan Writing Skill Pada Teks interaksi interpersonalmasih sangat rendah dan belum sesuai dengan yang diharapkan peneliti. Hal ini bisa dilihat pada tabel berikut.

Tabel 1. Data Hasil Belajar Siswa Pada Pra Siklus

\begin{tabular}{|c|c|c|c|c|c|c|c|}
\hline \multirow[t]{2}{*}{ No } & \multirow[t]{2}{*}{ Nama Siswa } & \multicolumn{2}{|c|}{ Hasil Yang di Capai } & \multirow[t]{2}{*}{ No } & \multirow[t]{2}{*}{ Nama Siswa } & \multicolumn{2}{|c|}{ Hasil Yang di Capai } \\
\hline & & Nilai & $\begin{array}{l}\text { NilaiTuntas/ } \\
\text { Tdk Tuntas }\end{array}$ & & & Nilai & $\begin{array}{c}\text { Nilai Tuntas/ } \\
\text { Tdk Tuntas }\end{array}$ \\
\hline 1 & Adila M & 65 & Tidak Tuntas & 14 & Oktiana & 80 & Tuntas \\
\hline 2 & Boyke R & 60 & Tidak Tuntas & 15 & Restu Penni A & 80 & Tuntas \\
\hline 3 & Eko Rahmat & 89 & Tuntas & 16 & Reza Okto & 85 & Tuntas \\
\hline 4 & Erni N S & 90 & Tuntas & 17 & Risma Yulianti & 75 & Tuntas \\
\hline 5 & Ersa Rahman & 60 & Tidak tuntas & 18 & Rizky Sitompul & 68 & Tidak Tuntas \\
\hline 6 & Ignasius & 66 & Tidak tuntas & 19 & Rizky Pratama & 80 & Tuntas \\
\hline 7 & Indah Sri W & 89 & Tuntas & 20 & Sabar & 85 & Tuntas \\
\hline 8 & Jenny & 68 & Tidak Tuntas & 21 & Sofia & 67 & Tidak tuntas \\
\hline 9 & Kristina & 65 & Tidak tuntas & 22 & Syahdila & 85 & Tuntas \\
\hline 10 & Kwangga & 80 & Tuntas & 23 & Tia Angelina & 60 & Tidak tuntas \\
\hline 11 & Lukman & 60 & Tidak tuntas & 24 & Tommy & 65 & Tidak tuntas \\
\hline 12 & M.Habib & 60 & Tidak tuntas & 25 & Yuda P & 66 & Tidak tuntas \\
\hline 13 & Nabilla & 67 & Tidak tuntas & 26 & Yuda Pratama & 69 & Tidak tuntas \\
\hline
\end{tabular}

Berdasarkan hasil dari kegiatan pra siklus diatas dapat disimpulkan pada tahap Pra Siklus ini dikatakan Ketrampilan Writing Skill Pada Teks interaksi interpersonaldi Kelas VII A masih rendah, hal ini disebabkan pembelajaran di kelas hanya bersifat transfer ilmu pengetahuan saja dan dilakukan secara konvensional dengan menyampaikan materi pelajaran sebanyak-banyaknya tanpa memperhatikan kebutuhan siswa. Dari tabel di atas dapat di lihat bahwa jumlah siswa yang tuntas belajar hanya 13 siswa atau $40 \%$.

\section{Hasil Penelitian Siklus 1}

Tahap siklus 1 di laksanakan pada tanggal 22 September 2016 dan 27 September 2016. Pada tahap ini pembelajaran dilaksanakan dengan menerapkan Tekhnik Pembelajaran Total Physical Response dengan tahapan sebagai berikut 
Astuti, Upaya Meningkatkan Ketrampilan Writing Skill pada Teks Interaksi Interpersonal dengan Menerapkan Teknik Pembelajaran Total Physical Response (Pada Siswa Kelas VII A SMP Negeri 8 Muaro Jambi)

\section{Perencanaan}

Adapun perencanaan dalam siklus 1 ini sebagai berikut:

- Memberikan stimulus berupa pemberian materi

- Mendiskusikan materi bersama siswa

- Memberikan kesempatan pada peserta didik mengkomunikasikan secara lisan atau mempresentasikan mengenai pembelajaran

- Menugaskan siswa menulis teks interaksi interpersonal

- Siswa diminta membahas contoh soal dalam Buku : Bahan Ajar Bahasa Inggris mengenai pertanyaan Teks interaksi interpersonal

\section{Pelaksanaan}

Adapun pelaksanaan dari kegiatan pembelajaran siklus 1 pada pertemuan 1 dan sebagai berikut :

Kegiatan Awal (10')

- Mengucapkan salam dengan ramah kepada siswa ketika memasuki ruang kelas (nilai yang ditanamkan: santun, peduli)

- Mengecek kehadiran siswa (nilai yang ditanamkan: disiplin, rajin)

- Mengaitkan materi/kompetensi yang akan dipelajari dengan karakter dengan merujuk pada silabus, RPP, dan bahan ajar, menyampaikan butir karakter yang hendak dikembangkan selain yang terkait dengan SK/KD

- Siswa berdiskusi mengenai pertanyaan yang tertera di buku teks

Kegiatan Inti (70')

Pertemuan ke 1

Eksplorasi

Dalam kegiatan eksplorasi guru :

- Memberikan stimulus berupa pemberian materi tentang penggunaan ungkapan Sapaan

- Mendiskusikan materi bersama siswa (Buku: Bahan Ajar Bahasa Inggris mengenai penggunaan ungkapan Sapaan.

- Memberikan kesempatan pada peserta didik mengkomunikasikan secara lisan atau mempresentasikan mengenai penggunaan ungkapan Sapaan

- Menugaskan siswa mengidentifikasi pola kalimat yang digunakan dalam ungkapan Sapaan

- Menugaskan siswa menulis beberapaungkapan sapaan

- Siswa diminta membahas contoh soal dalam Buku: Bahan Ajar Bahasa Inggris mengenai pertanyaan Teks interaksi interpersonal

Elaborasi

Dalam kegiatan elaborasi guru:

- Membiasakan peserta didik membaca dan menulis yang beragam melalui tugas-tugas tertentu yang bermakna.

- Memfasilitasi peserta didik melalui pemberian tugas, diskusi, dan lain-lain untuk memunculkan gagasan baru baik secara lisan maupun tertulis

\section{Konfirmasi}

Dalam kegiatan konfirmasi guru:

- Memberikan umpan balik positif dan penguatan dalam bentuk lisan, tulisan, isyarat, maupun hadiah terhadap keberhasilan peserta didik,

- Memberikan konfirmasi terhadap hasil eksplorasi dan elaborasi peserta didik melalui berbagai sumber,

- Memfasilitasi peserta didik melakukan refleksi untuk memperoleh pengalaman belajar yang telah dilakukan,

- Memfasilitasi peserta didik untuk memperoleh pengalaman yang bermakna dalam mencapai kompetensi dasar

\section{Pertemuan ke 2 \\ Eksplorasi}

Dalam kegiatan eksplorasi guru :

- Memberikan stimulus berupa pemberian materi tentang penggunaan ungkapan pamitan

- Mendiskusikan materi bersama siswa (Buku: Bahan Ajar Bahasa Inggris mengenai penggunaan ungkapan pamitan.

- Memberikan kesempatan pada peserta didik mengkomunikasikan secara lisan atau mempresentasikan mengenai penggunaan ungkapan pamitan

- Menugaskan siswa mengidentifikasi pola kalimat yang digunakan dalam ungkapan pamitan

- Menugaskan siswa menulis beberapaungkapan pamitan 
Astuti, Upaya Meningkatkan Ketrampilan Writing Skill pada Teks Interaksi Interpersonal dengan Menerapkan Teknik Pembelajaran Total Physical Response (Pada Siswa Kelas VII A SMP Negeri 8 Muaro Jambi)

- Siswa diminta membahas contoh soal dalam Buku: Bahan Ajar Bahasa Inggris mengenai pertanyaan Teks interaksi interpersonal

Elaborasi

Dalam kegiatan elaborasi guru:

- Membiasakan peserta didik membaca dan menulis yang beragam melalui tugas-tugas tertentu yang bermakna.

- Memfasilitasi peserta didik melalui pemberian tugas, diskusi, dan lain-lain untuk memunculkan gagasan baru baik secara lisan maupun tertulis

\section{Konfirmasi}

Dalam kegiatan konfirmasi guru:

- Memberikan umpan balik positif dan penguatan dalam bentuk lisan, tulisan, isyarat, maupun hadiah terhadap keberhasilan peserta didik,

- Memberikan konfirmasi terhadap hasil eksplorasi dan elaborasi peserta didik melalui berbagai sumber,

- Memfasilitasi peserta didik melakukan refleksi untuk memperoleh pengalaman belajar yang telah dilakukan,

- Memfasilitasi peserta didik untuk memperoleh pengalaman yang bermakna dalam mencapai kompetensi dasar

Kegiatan Akhir (10')

- bersama-sama dengan peserta didik dan/atau sendiri membuat rangkuman/simpulan pelajaran;

- melakukan penilaian dan/atau refleksi terhadap kegiatan yang sudah dilaksanakan secara konsisten dan terprogram

- memberikan umpan balik terhadap proses dan hasil pembelajaran

- Siswa diberikan pekerjaan rumah (PR) berkaitan dengan materi pembelajaran.

- menyampaikan rencana pembelajaran pada pertemuan berikutnya.

\section{Pengamatan}

Selama kegiatan pembelajaran berlangsung, peneliti bertindak sebagai observer yang bertugas mengamati kegiatan pembelajaran dengan mengisi lembar observasi yang telah disusun sebelum melaksanakan kegiatan penelitian. Hal ini dilakukan untuk mengetahui peningkatan ketrampilan siswa pada aspek Writing Skill Pada Teks interaksi interpersonal. Pada kegiatan belajar mengajar ini guru menggunakan Tekhnik Pembelajaran Total Physical Response .

Berdasarkan hasil pengamatan dapat dikatakan bahwa kegiatan pembelajaran yang di lakukan pada siklus 1 ini meski belum sepenuhnya berjalan kondusif dan sesuai dengan harapan peneliti, tetapi pembelajaran pada siklus 1 ini berjalan dengan lancar. Hal tersebut di karenakan siswa belum terbiasa dengan penerapan Tekhnik Pembelajaran Total Physical Response, sehingga siswa masih belum sepenuhnya memahami apa yang harus di lakukannya. Hal tersebut dapat di lihat dalam tabel berikut ini:

Tabel 2. Hasil Pengamatan Terhadap Siswa Kondusifnya Pembelajaran Pada Siklus 1

\begin{tabular}{clcc}
\hline No & \multicolumn{1}{c}{ Ciri Perilaku Siswa Dalam Melaksanakan Kegiatan Belajar Nya } & Ya & Tidak \\
\hline 1 & Siswa menulis Teks interaksi interpersonal dengan grammar yang tepat/sedikit kesalahannya & $\mathrm{v}$ \\
2. & $\begin{array}{l}\text { Siswa sudah menulis Teks interaksi interpersonal dengan kosa kata yang tepat/ sedikit } \\
\text { kesalahannya. }\end{array}$ & $\mathrm{v}$ \\
3. & Siswa menggunakan tanda baca yang benar dalam menulis Teks interaksi interpersonal & $\mathrm{v}$ \\
4. & Siswa dapat menulis Teks interaksi interpersonal dengan pola kalimat yang baik & $\mathrm{v}$ \\
5. & Siswa aktif bertanya & $\mathrm{v}$ \\
6. & Siswa mengikuti pembelajaran dengan semangat yang tinggi & $\mathrm{v}$ \\
7. & Siswa dapat menjawab pertanyaan guru dengan tepat saat KBM berlangsung & $\mathrm{v}$ \\
8. & Ada usaha dan motivasi untuk mempelajari bahan atau stimulus yang diberikan guru & $\mathrm{v}$ \\
\hline
\end{tabular}

Hasil belajar pada siklus 1 pada pembelajaran writing skill pada Teks interaksi interpersonalmulai menunjukkan adanya peningkatan. Siswa yang tuntas nilai belajarnya terhitung lebih banyak di bandingkan dengan perolehan hasil belajar pda pra siklus. Hal ini bisa dilihat pada tabel berikut.

Tabel 3. Data Hasil Belajar Siswa Pada Siklus 1

\begin{tabular}{lllccclc}
\hline No & Nama Siswa & \multicolumn{2}{c}{$\begin{array}{c}\text { Hasil Yang di Capai } \\
\text { Nilai }\end{array}$} & $\begin{array}{c}\text { NilaiTuntas/ } \\
\text { Tdk Tuntas }\end{array}$ & No & Nama Siswa & \multicolumn{2}{c}{$\begin{array}{c}\text { Hasil Yang di Capai } \\
\text { Nilai }\end{array}$} & $\begin{array}{c}\text { NilaiTuntas/ } \\
\text { Tdk Tuntas }\end{array}$ \\
\hline 1 & Adila M & 80 & Tuntas & 14 & Oktiana & 76 & Tuntas \\
2 & Boyke R & 80 & Tuntas & 15 & Restu Penni A & 66 & Tidak tuntas \\
3 & Eko Rahmat & 90 & Tuntas & 16 & Reza Okto & 85 & Tuntas \\
4 & Erni NS & 88 & Tuntas & 17 & Risma Yulianti & 88 & Tuntas \\
5 & Ersa Rahman & 90 & Tuntas & 18 & Rizky Sitompul & 65 & Tidak Tuntas
\end{tabular}


Astuti, Upaya Meningkatkan Ketrampilan Writing Skill pada Teks Interaksi Interpersonal dengan Menerapkan Teknik Pembelajaran Total Physical Response (Pada Siswa Kelas VII A SMP Negeri 8 Muaro Jambi)

\begin{tabular}{clllllll}
6 & Ignasius & 85 & Tuntas & 19 & Rizky Pratama & 80 & Tuntas \\
7 & Indah Sri W & 90 & Tuntas & 20 & Sabar & 80 & Tuntas \\
8 & Jenny & 80 & Tuntas & 21 & Sofia & 83 & Tuntas \\
9 & Kristina & 85 & Tuntas & 22 & Syahdila & 60 & Tidak tuntas \\
10 & Kwangga & 89 & Tuntas & 23 & Tia Angelina & 85 & Tuntas \\
11 & Lukman & 62 & Tidak tuntas & 24 & Tommy & 89 & Tuntas \\
12 & M.Habib & 95 & Tuntas & 25 & Yuda P & 60 & Tidak tuntas \\
13 & Nabilla & 85 & Tuntas & 26 & Yuda Pratama & 60 & Tidak tuntas \\
\hline
\end{tabular}

Berdasarkan hasil dari kegiatan siklus 1 diatas dapat disimpulkan pada tahap Siklus 1 ini dikatakan ketrampilan writing skill siswa pada Teks interaksi interpersonaldi Kelas VII A mulai menunjukkan adanya perubahan ke arah yang positif, yaitu jumlah siswa yang tuntas belajar dan mendapatkan nilai melebihi standar KKM lebih banyak di bandingkan dengan siklus sebelumnya. Pada siklus 1 ini siswa yang tuntas belajar sebanyak 20 siswa atau 77\%. Maka Tekhnik Pembelajaran Total Physical meningkatkan ketrampilan writing skill pada Teks interaksi interpersonaltepat sasaran. Berikut ini adalah grafik perbandingan jumlah ketuntasan siswa pada pra siklus dan siklus 1 :

Grafik 1. Perbandingan Jumlah Ketuntasan Siswa Pada Pra Siklus Dan Siklus 1
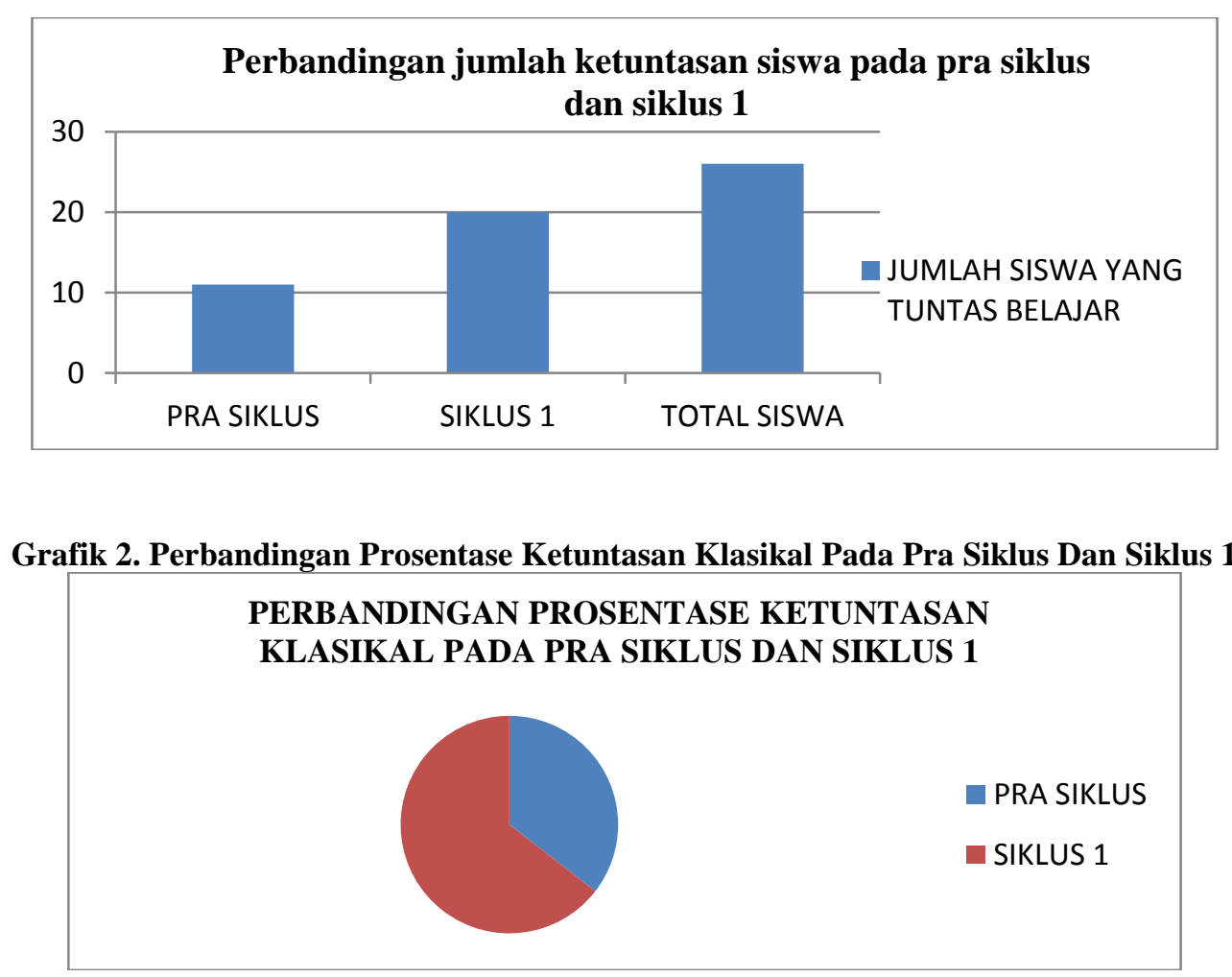

\section{Hasil Penelitian Siklus 2}

Tahap siklus 2 di laksanakan pada tanggal 29 September 2016 dan 6 Oktober 2016. Pada tahap ini pembelajaran di laksanakan dengan menerapkan Tekhnik Pembelajaran Total Physical Response dengan tahapan sebagai berikut

\section{Perencanaan}

Adapun perencanaan dalam siklus 2 ini sama dengan siklus 1.

\section{Pelaksanaan}

Adapun pelaksanaan dari kegiatan pembelajaran siklus 2 pada pertemuan 3 dan 4 sebagai berikut :

\section{Kegiatan Awal (10')}

- Mengucapkan salam dengan ramah kepada siswa ketika memasuki ruang kelas (nilai yang ditanamkan: santun, peduli)

- Mengecek kehadiran siswa (nilai yang ditanamkan: disiplin, rajin) 
- Mengaitkan materi/kompetensi yang akan dipelajari dengan karakter dengan merujuk pada silabus, RPP, dan bahan ajar, menyampaikan butir karakter yang hendak dikembangkan selain yang terkait dengan SK/KD

- Siswa berdiskusi mengenai pertanyaan yang tertera di buku teks

\section{Kegiatan Inti (70')}

Pertemuan ke 3

\section{Eksplorasi}

Dalam kegiatan eksplorasi guru :

- Memberikan stimulus berupa pemberian materi tentang penggunaan ungkapan terimakasih

- Mendiskusikan materi bersama siswa (Buku : Bahan Ajar Bahasa Inggris mengenai penggunaan ungkapan terimakasih.

- Memberikan kesempatan pada peserta didik mengkomunikasikan secara lisan atau mempresentasikan mengenai penggunaan ungkapan terimakasih

- Menugaskan siswa mengidentifikasi pola kalimat yang digunakan dalam ungkapan terimakasih

- Menugaskan siswa menulis beberapaungkapan terimakasih

- Siswa diminta membahas contoh soal dalam Buku : Bahan Ajar Bahasa Inggris mengenai pertanyaan Teks interaksi interpersonal

\section{Elaborasi}

Dalam kegiatan elaborasi guru:

- Membiasakan peserta didik membaca dan menulis yang beragam melalui tugas-tugas tertentu yang bermakna.

- Memfasilitasi peserta didik melalui pemberian tugas, diskusi, dan lain-lain untuk memunculkan gagasan baru baik secara lisan maupun tertulis

\section{$\underline{\text { Konfirmasi }}$}

Dalam kegiatan konfirmasi guru:

- Memberikan umpan balik positif dan penguatan dalam bentuk lisan, tulisan, isyarat, maupun hadiah terhadap keberhasilan peserta didik,

- Memberikan konfirmasi terhadap hasil eksplorasi dan elaborasi peserta didik melalui berbagai sumber,

- Memfasilitasi peserta didik melakukan refleksi untuk memperoleh pengalaman belajar yang telah dilakukan,

- Memfasilitasi peserta didik untuk memperoleh pengalaman yang bermakna dalam mencapai kompetensi dasar

Pertemuan ke 4 :

Eksplorasi

Dalam kegiatan eksplorasi guru :

- Memberikan stimulus berupa pemberian materi tentang penggunaan ungkapan permohonan maaf

- Mendiskusikan materi bersama siswa (Buku : Bahan Ajar Bahasa Inggris mengenai penggunaan ungkapan permohonan maaf.

- Memberikan kesempatan pada peserta didik mengkomunikasikan secara lisan atau mempresentasikan mengenai penggunaan ungkapan permohonan maaf

- Menugaskan siswa mengidentifikasi pola kalimat yang digunakan dalam ungkapan permohonan maaf

- Menugaskan siswa menulis beberapaungkapan permohonan maaf

- Siswa diminta membahas contoh soal dalam Buku : Bahan Ajar Bahasa Inggris mengenai pertanyaan Teks interaksi interpersonal

\section{Elaborasi}

Dalam kegiatan elaborasi guru:

- Membiasakan peserta didik membaca dan menulis yang beragam melalui tugas-tugas tertentu yang bermakna.

- Memfasilitasi peserta didik melalui pemberian tugas, diskusi, dan lain-lain untuk memunculkan gagasan baru baik secara lisan maupun tertulis

\section{$\underline{\text { Konfirmasi }}$}

Dalam kegiatan konfirmasi guru:

- Memberikan umpan balik positif dan penguatan dalam bentuk lisan, tulisan, isyarat, maupun hadiah terhadap keberhasilan peserta didik,

- Memberikan konfirmasi terhadap hasil eksplorasi dan elaborasi peserta didik melalui berbagai sumber,

- Memfasilitasi peserta didik melakukan refleksi untuk memperoleh pengalaman belajar yang telah dilakukan,

- Memfasilitasi peserta didik untuk memperoleh pengalaman yang bermakna dalam mencapai kompetensi dasar

Kegiatan Akhir (10)

- bersama-sama dengan peserta didik dan/atau sendiri membuat rangkuman/simpulan pelajaran;

- melakukan penilaian dan/atau refleksi terhadap kegiatan yang sudah dilaksanakan secara konsisten dan terprogram

- memberikan umpan balik terhadap proses dan hasil pembelajaran 
Astuti, Upaya Meningkatkan Ketrampilan Writing Skill pada Teks Interaksi Interpersonal dengan Menerapkan Teknik Pembelajaran Total Physical Response (Pada Siswa Kelas VII A SMP Negeri 8 Muaro Jambi)

- Siswa diberikan pekerjaan rumah (PR) berkaitan dengan materi pembelajaran.

- menyampaikan rencana pembelajaran pada pertemuan berikutnya.

\section{Pengamatan}

Selama kegiatan pembelajaran berlangsung, peneliti bertindak sebagai observer yang bertugas mengamati kegiatan pembelajaran dengan mengisi lembar observasi yang telah disusun sebelum melaksanakan kegiatan penelitian. Hal ini dilakukan untuk mengetahui peningkatan Ketrampilan Writing Skill siswa Pada Teks interaksi interpersonal. Pada kegiatan belajar mengajar siklus 2 ini guru masih menggunakan Tekhnik Pembelajaran Total Physical Response .

Berdasarkan hasil pengamatan dapat di katakan bahwa kegiatan pembelajaran yang di lakukan pada siklus 2 ini sudah bisa di nyatakan berjalan lebih kondusif dan sudah sesuai dengan harapan peneliti. Hal tersebut di karenakan siswa sudah paham dengan penerapan Tekhnik Pembelajaran Total Physical Response, sehingga siswa sudah memahami apa yang harus di lakukannya. Hal tersebut dapat di lihat dalam tabel berikut ini:

Tabel 4. Hasil Pengamatan Terhadap Siswa Kondusifnya Pembelajaran Pada Siklus 2

\begin{tabular}{|c|c|c|c|}
\hline No & Ciri perilaku siswa dalam melaksanakan kegiatan belajar nya & Ya & Tidak \\
\hline 1. & Siswa menulis Teks interaksi interpersonal dengan grammar yang tepat/sedikit kesalahannya & $\mathrm{V}$ & \\
\hline 2. & $\begin{array}{l}\text { Siswa sudah menulis Teks interaksi interpersonal dengan kosa kata yang tepat/ sedikit } \\
\text { kesalahannya. }\end{array}$ & & $\mathrm{v}$ \\
\hline 3. & Siswa menggunakan tanda baca yang benar dalam menulis Teks interaksi interpersonal & $\mathrm{V}$ & \\
\hline 4. & Siswa dapat menulis Teks interaksi interpersonal dengan pola kalimat yang baik & $\mathrm{v}$ & \\
\hline 5. & Siswa aktif bertanya & $\mathrm{v}$ & \\
\hline 6. & Siswa mengikuti pembelajaran dengan semangat yang tinggi & $\mathrm{v}$ & \\
\hline 7. & Siswa dapat menjawab pertanyaan guru dengan tepat saat KBM berlangsung & $\mathrm{v}$ & \\
\hline 8. & Ada usaha dan motivasi untuk mempelajari bahan atau stimulus yang diberikan guru & $\mathrm{V}$ & \\
\hline
\end{tabular}

Hasil belajar pada siklus 2 pada pembelajaran pada aspek wrting skill pada Teks interaksi interpersonalmenunjukkan adanya peningkatan. Hampir semua siswa mendapatkan nilai di atas KKM. Siswa yang tuntas terhitung lebih banyak lagi di bandingkan dengan perolehan hasil belajar pada pra siklus dan siklus 1 Hal ini bisa dilihat pada tabel berikut.

Tabel 5. Data Hasil Belajar Siswa Pada Siklus 2

\begin{tabular}{|c|c|c|c|c|c|c|c|}
\hline \multirow[t]{2}{*}{ No } & \multirow[t]{2}{*}{ Nama Siswa } & \multicolumn{2}{|c|}{ Hasil Yang di Capai } & \multirow[t]{2}{*}{ No } & \multirow[t]{2}{*}{ Nama Siswa } & \multicolumn{2}{|c|}{ Hasil Yang di Capai } \\
\hline & & Nilai & $\begin{array}{l}\text { NilaiTuntas/ } \\
\text { Tdk Tuntas }\end{array}$ & & & Nilai & $\begin{array}{l}\text { NilaiTuntas/Tdk } \\
\text { Tuntas }\end{array}$ \\
\hline 1 & Adila M & 90 & Tuntas & 14 & Oktiana & 85 & Tuntas \\
\hline 2 & Boyke R & 90 & Tuntas & 15 & Restu Pemi A & 85 & Tuntas \\
\hline 3 & Eko Rahmat & 85 & Tuntas & 16 & Reza Okto & 85 & Tuntas \\
\hline 4 & Erni N S & 85 & Tuntas & 17 & Risma Yulianti & 88 & Tuntas \\
\hline 5 & Ersa Rahman & 90 & Tuntas & 18 & Rizky Sitompul & 90 & Tuntas \\
\hline 6 & Ignasius & 90 & Tuntas & 19 & Rizky Pratama & 80 & Tuntas \\
\hline 7 & Indah S W & 88 & Tuntas & 20 & Sabar & 90 & Tuntas \\
\hline 8 & Jenny & 85 & Tuntas & 21 & Sofia & 90 & Tuntas \\
\hline 9 & Kristina & 87 & Tuntas & 22 & Syahdila & 86 & Tuntas \\
\hline 10 & Kwangga & 85 & Tuntas & 23 & Tia Angelina & 86 & Tuntas \\
\hline 11 & Lukman & 86 & Tuntas & 24 & Tomy & 90 & Tuntas \\
\hline 12 & M.Habib & 80 & Tuntas & 25 & Yuda P & 68 & Tidak tuntas \\
\hline 13 & Nabilla & 88 & Tuntas & 26 & Yuda Pratama & 66 & Tidak tuntas \\
\hline
\end{tabular}

Berdasarkan hasil dari kegiatan siklus 2 diatas dapat disimpulkan pada tahap Siklus 2 ini dikatakan Ketrampilan Writing Skill siswa Pada Teks interaksi interpersonaldi Kelas VII A menunjukkan adanya peningkatan yang sangat baik yaitu ada 24 siswa atau $92 \%$ siswa tuntas belajar dan mendapatkan nilai melebihi standar KKM, sementara itu hanya ada 2 siswa yang tidak tuntas. Maka Tekhnik Pembelajaran Total Physical Response dalam Meningkatkan Ketrampilan Writing Skill Pada Teks interaksi interpersonaltepat sasaran. Berikut ini adalah grafik perbandingan jumlah ketuntasan siswa pada pra siklus, siklus 1 dan siklus 2.

Grafik 3. Perbandingan Jumlah Ketuntasan Siswa Pada Pra Siklus, Siklus 1 dan Siklus 2 
Astuti, Upaya Meningkatkan Ketrampilan Writing Skill pada Teks Interaksi Interpersonal dengan Menerapkan Teknik Pembelajaran Total Physical Response (Pada Siswa Kelas VII A SMP Negeri 8 Muaro Jambi)
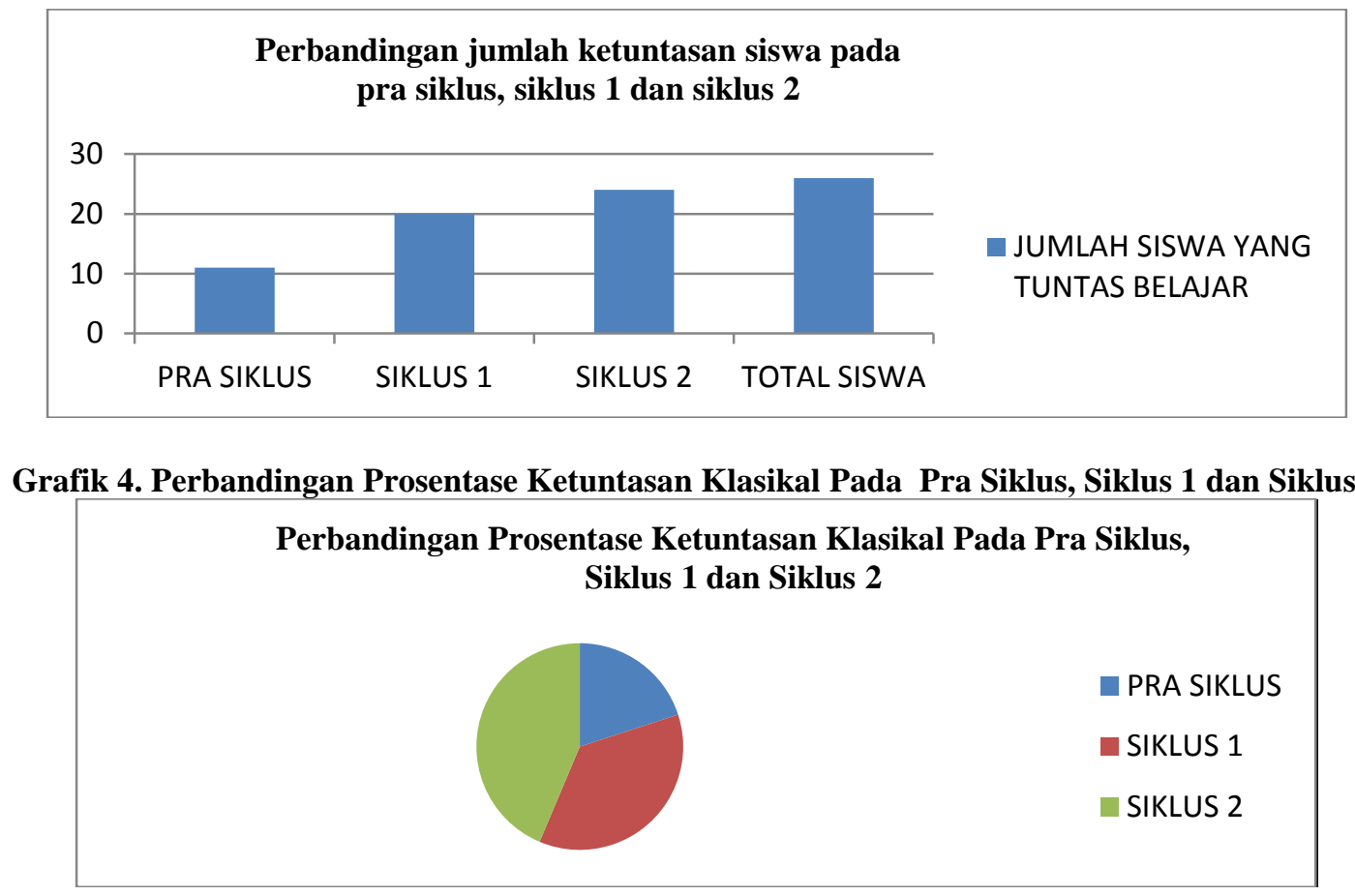

Pada proses pelaksanaan siklus ke-1 siswa diminta untuk mengikuti KBM dengan Tekhnik Pembelajaran Total Physical Response. Dengan Tekhnik Pembelajaran Total Physical Response yang merupakan suatu metode pembelajaran bahasa yang disusun pada koordinasi perintah (command), ucapan (speech) dan gerak (action); dan berusaha untuk mengajarkan bahasa melalui aktivitas fisik (motor), sehingga siswa lebih menguasai apa yang di ajarkan oleh guru.

Pada siklus 1 siswa yang tuntas belajar mencapai 20 siswa atau 77\%. Dari hasil pengamatan, hasil nilai dan wawancara pada siklus I, Tekhnik Pembelajaran total physical response secara efektif dapat meningkatkan ketrampilan writing skill pada Teks interaksi interpersonal pada siswa kelas VII ASMP Negeri 8Muaro JambiTahun Pelajaran 2016/2017.

Pada siklus ke 2 ini pelaksanaan Tekhnik Pembelajaran Total Physical Response hampir samaseperti yang di terapkan pada siklus I, dan hasil dari Tekhnik Pembelajaran Total Physical Response yang sudah dilaksanakan menunjukkan adanya peningkatanketrampilan writing skill pada Teks interaksi interpersonaldengan menerapkan tekhnik pembelajaran total physical response pada siswa kelas VII ASMP Negeri 8Muaro JambiTahun Pelajaran 2016 12017. Hal tersebut dapat di lihat dari jumlah siswa yang tuntas belajar pada siklus 2 ini mencapai 24 siswa atau $92 \%$ dari keseluruhan siswa.

\section{SIMPULAN}

Dari hasil penelitian yang dilakukan di kelas VII ASMP Negeri 8Muaro Jambi Tahun pelajaran 2016/2017, yaitu: "Upaya Meningkatkan Ketrampilan Writing Skill Pada Teks Interaksi Interpersonal dengan Menerapkan Tekhnik Pembelajaran Total Physical Response Pada Siswa Kelas VII ASMP Negeri 8Muaro JambiTahun Pelajaran 2016/2017" dapat disimpulkan berjalan secara kondusif danlancar. Pada prasiklus peneliti masih menggunakan metode konvensional dalam pembelajaran, siswa yang tuntas belajar pada pra siklus hanya 11 siswa atau $42 \%$ siswa mampu tuntas beajar. Kemudian pada siklus 1 peneliti mengadakan perbaikan pembelajaran dengan menerapkan Tekhnik Pembelajaran Total Physical Response. Hasilnya adalah pada siklus 1 ini jumlah siswa yang tuntas belajar meningkat menjadi 20 siswa atau 77\% siswa mampu tuntas belajar. Pada siklus 2 peneliti masih menggunakan Tekhnik Pembelajaran Total Physical Response dalam proses KBM, pada siklus 2 terdapat peningkatan jumlah siswa belajar menjadi 24 siswa atau 92\% siswa mampu tuntas belajar. Dengan konsep 4X pertemuan maka Tekhnik Pembelajaran Total Physical Response berdampak positif bagi proses peningkatan ketrampilan writing skill siswa pada Teks interaksi interpersonal. Adapun saran yang dapat diberikan dari penelitian ini adalah 1) bagi siswa : dengan meningkatkan writing skill, maka siswa akan lebih mudah dalam menulis teks-teks lain yang ada dalam pelajaranBahasa Inggris. Untuk dapat meningkatkan writing skill maka siswa harus mengikuti pembelajaran dengan baik, 2) Untuk para guru Bahasa Inggris: bagi para guru Bahasa Inggris teruslah mencari dan menerapkan metode yang pas dan cocok pada setiap sub materi pelajaran. Hal ini akan menunjang sekali pada tercapainya tujuan 
Astuti, Upaya Meningkatkan Ketrampilan Writing Skill pada Teks Interaksi Interpersonal dengan Menerapkan Teknik Pembelajaran Total Physical Response (Pada Siswa Kelas VII A SMP Negeri 8 Muaro Jambi)

pembelajaran, dan 3) Bagi kalangan umum: Bagi kalangan umum bisa membaca dan menjadikan referensi hasil tulisan saya ini.

\section{DAFTAR PUSTAKA}

Abimanyu, S. (2008). Strategi Pembelajaran. Jakarta: Direktoral Jendral Pendidikan Tinggi Depdiknas.

Arung, F. (2013). Keunggulan dan Kekurangan Metode TPR. Wordpress.

Dimyati. \& Mudjiono. (2006). Belajar dan Pembelajaran. Jakarta. Rineka Cipta dan Departemen Pendidikan dan Kebudayaan.

Faturrahman, P., \& Sutikno, M, S. (2007) Strategi Belajar Mengajar Melalui Konsep Umum dan Konsep Islam. Bandung, Refika Aditama.

Gapika.(2008). Totally Physical Response Metode Pembelajaran Yang Cukup Efektif Untuk Peserta Didik. Wordpress.

Indrianingsih, N. (2013). Total Physical Response. Jurnal Unesa.

Juanda. (2012). Total Physical Response. Wordpress.

Pasaribu, L.,\&Simandjuntak, B. (1983). Metode Belajar dan Kesulitan Belajar. Bandung : Tarsito.

Mukhlis, A. (2000). Penelitian Tindakan Kelas. Makalah Panitia Pelatihan Penulisan Karya Ilmiah untuk Guru-guru se-Kabupaten Tuban.

Surya, M. (2004). Psikologi Pembelajaran dan Pengajaran. Bandung: Pustaka Bani Quraisy. (1999). Proses Belajar Mengajar. Bandung: PT Remaja Rosda Karya.

Ngalim, P. (2006 ). Psikologi Pendidikan. Bandung : PT Remaja Rosda Karya.

Nasution. S (2006). Berbagai Pendekatan Dalam Proses Belajar Mengajar. Jakarta : Rineka Cipta.

Oemar, H. (2003). Proses Belajar Mengajar. Jakarta: Bumi Aksara.

Priyatni, E, T. (2002). Kurikulum Berbasis Kompetensi dan Pembelajaran Konteksual. Jakarta: Bumi Aksara.

Ratna Wilis. (1996). Teori-Teori Belajar. Jakarta: Erlangga.

Sanjaya, W. (2006). Strategi Pembelajaran Berorientasi Standar Proses Pendidikan. Bandung: San Grafika.

Sardiman, A.M (2009). Interaksi dan Motivasi Belajar Mengajar. Jakarta : PT. Raja Grafindo Persada.

Suharsimi, A. (2002). Prosedur Penelitian Suatu Pendekatan Praktek. Jakarta: Rineka Cipta.

Susilo.(2007).PanduanPenelitianTindakanKelas. YokyakartaPustaka Book Publisher.

Slavin, R, E. (2005). Metode Pengajaran Nasional. Penerbit Nusa Media, Bandung.

Widodo, H. P. (2005). Teaching Children Using a Total Physical Response (TPR) Method: rethinking. Bahasa dan seni, 33(2), 235-248. 